\title{
Linguo-Cultural Aspect of Interrelation of Language and Culture
}

\author{
Sevinj Hasanova ${ }^{1}$ \\ ${ }^{1}$ Azerbaijan University of Languages, Baku, Azerbaijan \\ Correspondence: Sevinj Hasanova, Department of English Lexicology, Azerbaijan University of Languages, \\ Baku, Azerbaijan. E-mail: sevinjhasanova@yahoo.com
}

Received: July 8, 2014 Accepted: November 9, 2014 Online Published: November 25, 2014

doi:10.5539/ijel.v4n6p160 URL: http://dx.doi.org/10.5539/ijel.v4n6p160

\begin{abstract}
The theme which we investigate, in comparison with other fields of linguistic study is comparatively new. Investigations show that linguocultural aspect of linguistic science appeared at the beginning of the XX century and gradually ousted country study. Despite the fact that linguoculturology is comparatively a new field of investigation, methodological foundations of study of problems of language and culture interactions are continuously being formed, a part of which, we have intended to embrace in this research work. The given research covers determination of the criteria of complex consideration of the problem, including the necessity of determination of the borders of linguoculturology and teaching this subject at schools and higher educational establishments, because linguocultural information becomes a necessary communicative part of the competence of the student, specific manner, realized in the semantics of language unit.

As it is known, linguoculturology studies interrelation of language and culture, but being different from culture-oriented linguistics, the main attention is focused on the linguistic aspect in this article.

In this research work attempts have been made to determine the object of investigation of culturology and discover types of culture, its layers, its ties with other fields of sciences, including humanitarian sciences among which are psychology, sociology and others. A special attention in the study of culturology is paid to cultural, social state and national features of people speaking this or that language and possessing the culture with all its self-belonging peculiarities.
\end{abstract}

Keywords: language, culture, concept, linguistic-cultural approach

\section{Introduction}

As it is known culture is the object of investigation of many branches of science, but different from culture-through-language studies, here the main attention is focused on the linguistic aspect. Linguo-culturology is associated with culture-oriented linguistics as a system of solving ruling principles of general education and humanitarian task, but besides it linguo-culturology possesses a number of specific peculiarities.

\section{Study of Linguo-Culturology}

Beginning with the XX century, linguo-culturology gradually ousted country study in the didactic plan as well. Since the last two decades of the XX century the term "linguoculturology" has been often used in association with the term "culture-through-language studies". Linguoculturology focuses attention onto the reflection of spiritual state in the language of a man in the society. This is just fully mentioned in the works of Bashurina in which she demands changing of shape of system of didactic coordinates: instead of systems of "teaching a language - acquaintance with culture" in the centre of attention stands interrelation between communicative competence with linguoculturology and culture-oriented linguistics in the system of "teaching a language acquaintance with culture - teaching a language".

Teliya, Maslova and the works of others serve to create these sources. As to Teliya methodological basis of linguoculturology serves "semiotic presentation indications of this interaction, considered as cognitive contents of mental procedures, the result of which is cultural liqualization of mental structures" (Teliya, 17). Supporting this view point, at any rate it is necessary to mention that such vision of object of linguoculturology does not sufficiently distinguish its contours from adjacent scientific subjects. In any case it is necessary to consider object of culturology: language as a means of representation of cultures or culture, considered in the light of language. Despite their obvious "relationship", it is necessary to distinguish cognitive culturology from cognitive 
linguistics. Different from "pure" cognitive science, culturology, as other fields of science, studying humanitarian meaning "can't develop at the cost of ideals of "scientific character" and objective character of natural sciences, leaving alone formalized knowledge". However linguoculturology is a science which can't help doing a thing without principles of scientific understanding of the world. Accordingly, there exists non formalized "bastions" of scientific character, where 'a certain portion of methodologism takes place and analytics successfully coordinate narrative character of "story" with free way of thinking and this takes place on the intersection of different "horizons" of culture, science and art (Mikeshina, 499-500).

For the linguoculturology such an approach is quite natural, because on the determination of Ricker "from the point of view of narration, life in the world is just the life in the world, being already marked with the language practice, linked with this understanding beforehand" (Riker, 99). Necessity of combinative approach to the objects of culture, in which narrative, literary thinking and elements of methodological analysis are organically supposed to exist, are conditioned by the demand of linguoculturology in an indefinite discourse - thinking space; between strict scientific character and free fantasy. The first is unacceptable as to its abstractness and as to the reason in which exists methodological constraint on the products of discourse understanding and the second as absolutely non restricted imagination - as it is also unacceptable.

The last example of harmonic combination of mentioned approaches is considered by the well-known "Fall of middle ages" of Heising, containing in itself, not only stylistics of "narration"; poetry, but also elements of deep methodological analysis. Nevertheless, Heising himself was not welcomed by "historical works written in belles-lettres style". But his longing for free and creative thinking may serve to linguoculturology as a certain example of mutually completion of science and narrative.

\section{Methodology of Linguo-Culturology}

The nature of humanitarian science itself surmises a special type of "culturological" methodology, including variety of "language games" with obligatory presence of narrative elements. It is worth mentioning that such a methodology is not usual and is a very understandable means. It is not a logical understanding, and in itself is a notion of a key is not something abstract or taken as to analogy, but first of all concretely formalizing, but not determining exactly, and adjoining the self-peculiarity of the object and occurrences. Such ordinary notions are close to the modern cultural "conception", able to be actualized in different "contexts".

On the basis of linguocultural methodology lies ordinary notion of special type: "concepts of word-forming" which do not turn into abstract notions and are enriched, thanks to lively, but not "theoreticalized" narration, the search of culture in facts is just the sense of life.

Therefore, search of methodological bases of linguoculturology is realized by the way of using elements of concentrology, Germanistics and general philology. In conformity with such a methodological vector at the modern stage of development of linguoculturology, attempts are made to integrate into linguistic methods of receptions and methods of culturology: general philosophical, ideographical (descriptive) method of Vindelband, inductive method (Shiller \& Gartman), phenomenological method (Gusserl), hermeneutical method (Gadamer), structural-functional analysis (Levi-Stros and others).

In this plan several methods of linguoculturology can be distinguished:

1) diachronical method based on comparative analysis of different linguocultural units as to the time;

2) synchronic method, comparing simultaneously existing linguoculturological units;

3) structural-functional method, surmising division of the objects of culture into parts and discovering links among the parts;

4) historical-genetic method, oriented to the study of linguocultural facts from the point of view of its formation, development and its further fate;

5) typological method, aimed at discovery of typologically closeness of different linguocultural units, created during historico-cultural process:

6) on the basis of comparative-historical method lies the comparison of original linguocultural units as to the time and analysis of their essence.

\subsection{Speech Portrait}

During the last time on the method or representations of concepts, methods peculiar to linguoculturology are worked out. In this, they think that the ways of objectification of the concepts running as to the hermeneutical circle, supply linguo-cultural possibilities of creating speech-thinking "portrait of the object of notion". In the 
process of creating such a "portrait" when individually taken fragments (elements) of the character of the object is drawn, linguocognitive selection and interpretation of individually taken words, giving cultural meanings (as to the origin, quality, appearance, function and as to their duration of existence) and other marked codes in the type of seven semantic structures of the words (phraseologisms, idioms), take place. So, creation of speech portrait of this or that object, as to Bartminskiy, is a means of establishment of minimal meaningful elements within the language meaning. Meaningful elements themselves are derivative, which appear in the process of fixation of interpreted by the human being, features, signs, peculiarities, qualities and by the function of cognized object. We consider them as the results of prototype semantics. Selected by this way signs are called profiles by Bartminskiy "Different profiles are not different meanings, but they are the ways of organizing the meaning structures of this and that meaning. ...The notion of prototype can be considered as profiling of its type, accepting the fact of existence of prototype profile and its derivatives" (Bartminskiy, 220).

The result of process of creating speech portrait of the object - profiling by Bartminskiy is considered as profile. His main difference between the conception of Langaker stands just in this. As to Bartminskiy profiling means "section", the search of borders of social conscious (Bartminskiy, 33). In the conceptions of Bartminskiy and Langaker the main profiling differs: in the first conception social, ethno-cultural conscience is meant, while in the second the subjective, individual conscience is meant. Different from Langaker who stands for limited profiling of the limits of observation (Langaker, 28-33), Bartminskiy considers that different codes form limits for experience: verbal, behaviorist, mystic-ideological, objective-symbolic.

\subsection{Visual Method}

It is worth speaking of not only on different ways of conceptual analysis, but also of purposefulness of their complex usage. Domination of this or that tandem in this problem determines the specific feature of proper method: visual method by Langaker: method of profiling by Bartminskiy and his school; description of predicative links and modeling of diagnostic contexts; description of concept as to its association field; analysis of meaning as to the vocabulary definition; etymological analysis; method of studying concepts through the lexic-grammatic fields of lexeme, representing it.

\subsection{Linguocultural Approach}

Supporters of linguocultural approach to the understanding of disciplinary status of linguoculturology, demonstrate its general genetic roots, linked with linguistics, associating it with the appearance of linguistic doctrines worked out by Humboldt, Bundt, Shukhardt, Potebnya and others. Within this didactic approach Prokhorov considers that culture of a country is considered as a constituent part of communicative necessities of learning the language, extra linguistic basis of speech situations and realized intentions in it. "The aim of teaching is to supply communicative competences of the learners" (Prokhorov, 96).

The subject of linguistic culturology is language as the realization of the start of creative spirits of the human being, as the reflection of cultural values of ethnic society, and the central problem is the problem of learning the language picture of the world, peculiar for each language collective (Vorobyov, 45). As Vorobyov affirms, deepening of semantics till the level of "subject syntagmatics" supplies ability to analyze verbalized act of culture as the unity of language and out of language (extra-linguistic) essence. Accordingly, linguoculturology is directed to the analysis of out of language contents of culture as well, giving advantage to the last notion.

As to Prokhorov in linguoculturology more abstract level of description of the problem of mutual relationship of language and culture is given. Nevertheless the author puts the teaching of culture in the first place, but alongside with it, he indicates the necessity of complex consideration of three criteria:

1) language, criterion including frequency of usage of language units, taking the given borders into consideration;

2) acquainting criterion, being realized in the understanding of teaching-methodical purposefulness;

3) culturological criterion, surmising to take the degree of importance into account, and urgency of the information from the position of knowledge of the given field.

In accordance with this, we may come to the conclusion that during the teaching of a foreign language in an auditorium, the usage of linguocultural approach is a must, because linguocultural information becomes a necessary communicative part of the competence of the student, specific manner realized in the semantics of language unit. Linguocultural knowledge makes forming linguocultural competence, as a part of communication, necessary. Linguoculturologic competence includes study of linguoculturology, phenomenon of culture, but not the phenomenon of language. 
As an example of the above mentioned we'll consider the following text:

I was a very good student, if I may say so. I was tops at St. Michael's College four years in a row. I got every possible award from the Department of Zoology... I would have received the Governor General's Academic Medal, The University of Toronto's, ... were it not for a beef-eating pink boy with a neck like a tree trunk... (15, Martel Y., p. 5).

In the given extract we observe phenomenon of cultural framing, where absolutely negative attitude of the speaker is expressed implicitly in the word combinations: "beef-eating pink boy", which indicates cultural, religious, racial and social discrimination between the speaker and the discussed person.

Analysis of methodic literature makes it possible to determine linguocultural approach as one of the most efficient one, aimed at formation and improvement of habits and skills of realization of intercultural intercourse by means of learning a language phenomenon of culture.

The result of forming the second cognitive conscience in the student by means of mastering a foreign language is gaining by them the ability of intercultural communication. Alongside with the language with such an approach to the culture includes the main contents of teaching, which meets the psychological peculiarities of learning a foreign language.

Linguocultural approach gives possibility to keep away from simplified factologic-fragmental acquaintance of the learned language, with definite aspects of culture, which makes it possible for the learners to form complete enough picture of "out of language activity" by means of investigating both lingual and out of language contents of chosen sphere for learning.

As in the didactic interpretation of linguo-culturology introduces itself as theoretical foundation of forming the second language personality, of those communicative skills, which are necessary for learning different national pictures of the world and prevention of cultural interference, then linguocultural approach in learning the Russian language as a foreign language is one of the conditions of mastering lexis, supplying intercultural communication. A foreigner's learning lexis and mastering it in the linguocultural aspect makes transition possible to another mark system, necessary for forming the second language personality. In the modern methodology by mastering a language we understand as ability to communicate with another person correctly, freely and adequately in the language that the person has mastered. So, as we see, the language picture of the world deepens till the linguo-cultural picture of the world as a system of knowledge on culture, expressed in a definite national language, but an individual usage of linguoculture is substituted by linguocultural competence as a socially meaningful system.

Completing Vorobyov's determination for the methodical purposes, Bashurina under the term of linguocultural competence understands system of knowledge on the culture, used in a definite national language and the complex of skills of operating with this knowledge. The author proves, that ability to intercultural communication is the result of forming the second cognitive conscience in the learners by means of learning any foreign language which can be achieved in the process of culturological learning, representing fragments of culture. So, culturological approach to culture becomes the object of cognition and teaching.

As it is known, linguoculturology studies interrelation of language and culture, but being different from culture-oriented linguistics, the main attention is focused on the linguistic aspect. Linguoculturology is linked with culture-through-language studies as a system of ruling principles of solving general schooling and humanitarian tasks, but besides it, linguoculturology possesses a number of specific features:

1) it is a subject of synthetic type, occupying bordering position between science and, learners of culture and philology;

2) the main object of culturology is interrelation of language and culture and interpretation of this interaction;

3 ) as the subject of investigation of linguoculturology serves spiritual and material culture, verbalized artefacts, forming "the language picture of the world";

4) linguoculturology is oriented to the new system of cultural values, put forth by the modern life in the society, to the objective information on the cultural life of the country (Vorobyov, p. 32).

Being busy learning cognitive semantics at the XX-XXI centuries sometimes, consciously or unconsciously some people think that systematic-structural aspects of linguistic analysis has expired its heuristic potential. Bondarko, criticizing such a mistaken conception, puts forth his understanding, stressing the fact that development of cognitive semantics does not contradict systematic-structural approach, but on the contrary it completes it. 
Their combination is possible from the point of view of description of means of formal expression of language meaning and from the view-point of systematic modeling of semantic category of the language and speech (language unit, speech and even the whole text). There is no doubt that we must speak on the systematic-cognitive investigation of language semantics.

Besides, it doesn't mean, that simple unification of semantics with systematic-structure and semantics with cognition is possible. Absence of one general principle contradicts its systematic-structural semantics which studies the contents of words, from the position of object (logical approach), but cognitive semantics studies from the position of subject (anthropocentric approach). Some scientists express their thoughts, saying that these two approaches are not compatible.

We think that there is no ground here to speak about incompatibility of methodical positions; on the contrary systematic-structural approach does not contradict strategic basis of cognitive semantics. The last one, in spite of the fact that mainly is guided by semantic vision of the object in all its wholeness and complicity, at any rate we can't help thinking on the analytical understanding of real truth-without division of the whole into the parts and determining between them objective law of correlation and relations. Moreover, synthesis suggests analytical thinking: before synthesizing the cognizable event, it is necessary to know that at this moment modeling of the picture of the world or its individually taken fragments should be taken as mental integration. At any rate such kind of arguments remain unconvincing, unless we specify, what systematic-structural semantics is dealt with.

At present object of linguoculturology is the language-discourse activity, considered by the value-meaningfulness view point. Such a determination of the object of linguoculturology derives from Humboldt conception, according to which, language takes active part in all important spheres of cultural-discourse life; in thinking and understanding the reality. "Language in accordance with the considered conception, is a universal form of the initial conceptualization of the world, expresser and safe-keeper of unconscious, spontaneous knowledge on the world, historical memory on the socially meaningful events in the human life. Language is a mirror of culture reflecting the images of passed culture, intuition and categories of world outlook" (Postovolova, 30).

Ideas of B. fon Humboldt successfully developed in the Russian science. For example, Tolstoy thought that relations between culture and language can be considered as the relation of a whole and its parts. Language can be apprehended as a component of culture or instrument of culture, particularly, when we deal with literary language or the language of the folklore. At the same time in relation with culture, it is as a whole, autonomous. It can be considered apart from culture, which is being done by "pure" systematic-structural linguistics or in comparison with culture it is considered as a phenomenon of equal meaning and equal right. Consideration of these two objects separately, and at the same time, comparatively, makes it possible to apply a number of terms and notions related to culture, used and becoming old in the linguistics. Such an expansion of "linguistic approach to the phenomena of culture in no case can be considered as something of "transition" of terms of culturology to the linguistic terms, but with structurally more exact approach to culture as something like semantic whole.

\section{Culture and Language}

Comparison of culture and language as a whole and particularly in a concrete national culture and in a concrete language discovers something isomorphism in their structure, in functional and hierarchic plan. Accordingly, by the way of discriminating literary language and dialects, specifying in them common speech and in some cases argot too, in any ethno-culture Tolstoy distinguished four types of culture: a) culture of educated layer (stratum) "bookish" or elitist; b) people's culture, peasantry culture; mediating culture, fitting to common speech, which is usually called "culture for people" or "the third culture"; c) traditional-professional subculture (shepherds, bee-keepers, potters and tradesmen-handicraftsmen's culture) (Tolstoy, 235).

Scientists put forth two parallel strata having made some changes in the enumerated language and cultural layers:

literary language -élite culture

popular language - "the third culture"

dialects and sayings - popular culture

argot - traditional-professional culture

For the both rows one and the same type-setting of different indications can be applied:

1) standardization - no standardization 
2) overdialectivity (overterritoriality) - dialectivity (territorial membering);

3) openness - closeness (sphere, systems);

4) stability - no stability.

Each separately-taken language or cultural stratum is characterized by definite combinations of indications, for example, for the literary language this is standardization, overdialectization, openness, stability, but each column - by means of weakening of indications and by changing into its contradictory indication, for example from standardization of literary language till non standardization of argot, or from vernacularism of elitist culture till dialectalization of traditional-professional culture.

All this can be related, first of all, to the prehistory of science on the correlation of language and culture. First of all, notes on the linguoculturology and object of science were mentioned in the works of Pokrovskiy, Stepanov, Likhachev and Lotman.

It is necessary to mention that beginning with the XIX century, the problem of language and culture always were in the centre of attention of philosophers, linguists and culturologists basing on anthropocentric principles of cognition and description of the world. In the limelight of culturology, at the end of the XX century, seemed to be not only language, but discourse, in which by different languages and discourse elements proper character of world was introduced.

Particularly deeply this view-point is substantiated in the works of Teliya. In her conception linguoculturology, being different from other types of culturological subjects is destined to study lively communicative processes in their synchronic links with ethnic mentalists, acting in the given cultural era. In such an understanding the tasks of culturology, the object of its investigation becomes "archeology of culture". Linguistic "excavation" of cultural-historic layers here are realized with the help of such categories as national picture (character, model) of world, language (ethno-cultural) conscience and mentality of the people. The mentioned category, we must say that doesn't make synonymy, each of them has possessed its own meaningful feature (Teliya, 35).

All these categories unite so called national (ethnic) component. At the beginning of the XX century, many of the Russian philosophers showed the importance of the national (ethnic in our terminology) roots in the life of human society, as for ex. in the works of Berdyayev, Ilyin, Trubetskoy. As to Berdyayev, out of nationality, which is understood as individual life, a society cant exist. Just through national individuality each individual person enters the humanity, that person enters the humanity as a national individual (Postovalova, 232-233).

Ilyin as the law of human nature and culture understands that "all the great ideas can be uttered by a man or by the people only by its self belongingness and all the genius ideas appear only in the bosom of national experience, spirits and wisdom". Losing its ties with ethno-cultural ties, a man looses admittance into the deepest well of spirits and to the saint fire of life, which is always national: in it survives the whole century of works, suffering fight, maturity, praying and thoughts of all people". For the linguoculturology extremely important factor is Ilyin's accent on the nationality of a person which is established unconsciously, but by the way of instinct and by his creative act, appeared unconsciously" (Mikeshina, 236-237).

These thoughts of the scientist are just not only in relation with culture in general: they are specifically essential and are restricted for the linguoculture.

Judging by how a man trusts, how he prays, how he does his praying, how and in what speech examples the man's honour, sense of duty appear; how he sings, reads poems, it is possible to determine to what nationality the boy belongs. We must mention that all this depends not only on the conscious behavior of a man, but also on the spiritual state of the person, which appears unconsciously.

\section{Conclusion}

Having investigated "Linguocultural aspect of interrelation of language and culture we have come to the conclusion that linguoculturology is a new aspect of complex approach to language and culture, their interrelation with each other, mutual enfluence on the development of culture and language, their links with social life, psychology, and philosophy.

In the study of culturology the following methods of investigations were used: 1) diachronical; 2) synchronical; 3) structural functional; 4) historical-genetic; 5) typological; 6) comparative-historical methods.

During the last time on the method or representations of concepts, methods peculiar to linguoculturology are worked out. As it is indicated in the article the ideas of the scholars in this issue differ, but taking all these peculiarities on the differentiations of the ideas into consideration, still it has been possible, to achieve a general notion on the cultrolinquistic aspect of the language study. 
We support the idea on the linguoculturology telling that linguistic approach to the phenomena of culture in no case can be considered as something of "transition" of terms of culturology to the linguistic terms, but with structurally more exact approach to culture as something like semantic whole. All the great ideas can be uttered by a man or by the people only by its self belongingness and all the genious ideas appear only in the bosom of national experience, spirits and wisdom. Judging by how a man trusts, how he prays, how he does his praying, how and in what speech examples the man's honour, sense of duty appear, how he sings, reads poems, it is possible to determine to what nationality the person belongs. We must mention that all this depends not only on the conscious behavior of a man, but also on the spiritual state of the person which appears unconsciously.

\section{References}

Alfirenko, N. F. (2005). Disputable problems of semantics.

Auerbakh, E. (2000). Mimesis Reflection of reality in West-European Literature.

Bartminski, E. (1980). Ethnocentrism of a stereotype Vocal and mental stereotypes synchrony and diachrony. Theses of conference, Novosibirsk.

Cherneyko, D. (2003). Linguaculture and cognition. Moscow.

Langacker, R. W. (1991). Foundations of Cognitive Grammar, Vol. 2, Descriptive Application. Stanford, California: Stanford University Press.

Lurye, S. A. (1997). Ethno-cultural specifics of lingual awareness of Russians and English. Moscow.

Martel, Y. (2003). Life of Pi. Edinburgh: Canongate Books Ltd.

Mikeshina, L. A. (2002). The philosophy of cognition.

Postovalova, V. I. (1999). Linguaculturology in the aspect of anthropological paradigm, Phraseology in the context of culture. Languages of Russian culture.

Prokhorov, U. E. (2009). Reality. Text. Discourse. M., Flinta, Nauka.

Riker, P. (2002). The conflict of interpretation. Translated from French by Vdovina I. S., M. Kanon-Press-C, Kuchkovo pole.

Teliya, V. N. (1999). Phraseology in the context of culture. Languages of Russian culture, Moscow.

Teliya, V. N. (2008). Linguaculturology - the key to new reality. Langage. Culture. Communication. The collection of scientific works.

Tolstoy, N. I. (1998). Language and folk culture. Selected works of Slavic literary-lingual situation. Slovo, Moscow.

Vorobyov, V. V. (1997). Lingua-culturological principals of presentation of educational material. The problems of concentrism, Moscow.

\section{Copyrights}

Copyright for this article is retained by the author(s), with first publication rights granted to the journal.

This is an open-access article distributed under the terms and conditions of the Creative Commons Attribution license (http://creativecommons.org/licenses/by/3.0/). 